\title{
SER MÃE E A RE-DESCOBERTA DO SABER NA ESTIMULAÇÃO NATURAL DE SEUS FILHOS'
}

\author{
Ivone Evangelista Cabral ${ }^{2}$
}

\section{Professora Orientadora: Maria Antonieta Rubio Tyrrell}

O saber próprio da mãe, como resultado de um processo de acumulação de informações que foram transmitidas pela cultura, influi consideravelmente na forma de lidar com seus filhos que apresentam comprometimento no desenvolvimento decorrente de agravos nutricionais. $\mathbf{O}$ interesse para investigar esse saber, sua origem e construção ao longo do tempo surgiu da observação do comportamento das mães com seus filhos, internados numa enfermaria de recuperação clínico-nutricional. Os estudos revelados pelas enfermeiras nas duas últimas décadas têm revelado a supremacia do "saber científico" dos profissionais da área de saúde, em detrimento do "saber da mãe". Por levarem em consideração apenas o conhecimento oriundo das ciências, especialmente da psicologia do desenvolvimento infantil, elaboram os programas de estimulação como recurso técnico para incrementar o desenvolvimento das crianças, em que as mães atuam mais como expectadoras do que como interventora. $\mathrm{O}$ estudo foi desenvolvido com um grupo de mulheres-mães de crianças acompanhadas no Programa de Acompanhamento do Crescimento e desenvolvimento de um ambulatório da rede municipal de saúde do Rio de Janeiro. Dentre os métodos de pesquisa qualitativa, optamos pelo estudo de caso de um grupo. Desenvolvemos dinâmicas de grupo (linha da vida, corpo-cidadania e árvore da vida) por conta de uma experiência vivenciada nos trabalhos de LIMA. A triangulação dos dados, obtida através das dinâmicas de grupo, entrevista individual semi-estruturada e análise de programas, facilitou a categorização dos achados. $\mathbf{O}$ grupo de oito mulheres, inclusive a investigadora, nos formeceu dados que foram assim categorizados: a) 0 contexto da familia-propósitos e práticas organizativas no processo de socialização das mulheres; b) 0 contexto sóciopolítico no processo de transformação da mulher-mãe; c) As práticas organizativas que influiram no processo de socialização da mulher-mãe; d) Re-descobrindo o "saber" da mulher-mãe na estimulação natural. Associado a isto, o confronto entre literatura e achados, ao mesmo tempo que revela uma confluência entre a cultura popular (saber do senso comum), na concepção de GRAMSCI, e cultura formal (saber científico), aponta inexistência de aliança entre os dois saberes. Existem evidências práticas e teóricas de pouca utilização desse saber quando do comprometimento no desenvolvimento do filho. 0 saber da mulher-mãe na estimulação dos filhos manifesta-se naturalmente, apesar dos conflitos, negações e confirmações, contradições e antagonismos.

\footnotetext{
${ }^{1}$ Dissertação de Mestrado. EEAN. UFRJ. Rio de Janeiro

${ }^{2}$ Mestra em enfermagem. Profa. Assist. do DEMI-EEAN/UFRJ
} 